\title{
Influence of Process Conditions on Measles Virus Stability
}

\author{
${ }^{1,2}$ Weiss, K., ${ }^{1,2}$ D. Salzig, ${ }^{1,2}$ Y. Röder, ${ }^{1,2}$ J. Gerstenberger, \\ ${ }^{3,4}$ M.D. Mühlebach, ${ }^{3,4}$ K. Cichutek, ${ }^{5}$ R. Pörtner and ${ }^{1,2,6,7}$ P. Czermak \\ ${ }^{1}$ Institute of Bioprocess Engineering and Pharmaceutical Technology, Faculty of Biotechnology-KMUB, \\ Mittelhessen University of Applied Sciences, Wiesenstrasse 14, 35390 Giessen, Germany \\ ${ }^{2}$ German Center for Infection Research, Mittelhessen University of Applied Sciences, Giessen, Germany \\ ${ }^{3}$ Oncolytic Measles Viruses and Vectored Vaccines, Paul-Ehrlich-Strasse 51-59, 63225 Langen, Germany \\ ${ }^{4}$ German Center for Infection Research, Paul-Ehrlich-Strasse 51-59, 63225 Langen, Germany \\ ${ }^{5}$ Institute of Bioprocess and Biosystems Engineering, \\ Hamburg University of Technology, Denickestraße 15, 21073 Hamburg, Germany \\ ${ }^{6}$ Department of Chemical Engineering, Faculty of Engineering, Kansas State University, Manhattan, KS 66506, USA \\ ${ }^{7}$ Department of Chemistry, Faculty of Biology and Chemistry, Justus-Liebig-University Giessen, 35390 Giessen, Germany \\ Received 2013-05-14, Revised 2013-07-20; Accepted 2013-08-06

\begin{abstract}
Recombinant measles viruses are currently tested in clinical trials as oncolytic agent to be applied in cancer therapy. Contrary to their use as vaccine where $10^{3}$ infectious virus particles per dose are needed, for cancer therapy $10^{9}$ virus particles should be provided per dose. This leads to other challenges for the production process when compared to vaccine production. This study presents measles virus stability with regard to conditions during production and storage of the virus. Relevant process parameters such as temperature (4$\left.37^{\circ} \mathrm{C}\right), \mathrm{pH}(\mathrm{pH} 4-11)$, conductivity $\left(1.5\right.$ to $137.5 \mathrm{mS} \mathrm{cm}^{-1}$ ) and oxygen partial pressure were analyzed. The infectivity of measles virus particles decreased highly at 37 and $32^{\circ} \mathrm{C}$, while at 22 and $4{ }^{\circ} \mathrm{C}$ it remained stable for several hours or even days, respectively. The thermal inactivation reactions followed first order kinetics and the thermodynamic parameters enthalpy and entropy were estimated. Towards changes in $\mathrm{pH}$ measles virus particles were very sensitive, while no inactivation could be observed with varying conductivity. Measles virus incubation at an oxygen partial pressure of $100 \%$ did not lead to any loss of infectivity. The results show which parameters should be considered and controlled strongly in the production process to further raise measles virus yields for the high amount needed in cancer therapy approaches.
\end{abstract}

Keywords: Measles Virus, Virus Stability, Virus Inactivation, Oncolytic Agent

\section{INTRODUCTION}

As a member of the order Mononegavirales (family: Paramyxoviridae), Measles Virus (MV) is an RNA virus with a single stranded genome in negative-sense orientation. The genome is wrapped in a Ribonucleoprotein (RNP) complex and enveloped by a lipid layer containing the viral glycoproteins hemagglutinin and fusion protein (Navaratnarajah et al., 2009). The virus particles have a size of 120-270 nm. MV is the causative agent of the disease measles, which is highly infectious and characterized by the so called Koplik spots, high fever and a weakened immune system. Although the course of disease is often relatively mild, life-threatening complications such as Subacute Sclerosing Panencephalitis (SSPE) appear with relative low frequency, but regularly (Sabella, 2010). These complications can be prevented by vaccination with attenuated MV vaccine strains which have been $\begin{aligned} \text { Corresponding Author: } & \text { Czermak, P., Institute of Bioprocess Engineering and Pharmaceutical Technology, Faculty } \\ & \text { Mittelhessen University of Applied Sciences, Wiesenstrasse 14, } 35390 \text { Giessen, Germany }\end{aligned}$ 
used in several millions of doses and have revealed an excellent safety profile.

MV induces a Cytophatic Effect (CPE), i.e., cellto-cell fusion and the formation of multi-nucleated giant cells, ultimately leading to induction of apoptosis and killing of infected cells. Current studies in cancer therapy try to take benefit of this inherent cytotoxicity, as derivatives of an MV vaccine strain are currently tested in clinical trials for cancer therapy (Msaouel et al., 2012). The ability of MV to kill cancer cells has been correlated to cell entry of attenuated MV via CD46; this receptor is frequently over-expressed on tumor cells (Anderson et al., 2004). Preclinical, unmodified and recombinant MV strains have revealed oncolytic potency in numerous models including xenograft tumor models of human lymphoma (Grote et al., 2001), ovarian cancer (Peng et al., 2002), or prostate cancer (Msaouel et al., 2009).

The infectivity of MV particles is the basic requirement for the success of oncolytic virotherapy. Moreover, the amount of virus particles for one therapeutic dose is up to 3 to $6 \log _{10}$ units higher than those traditionally used for vaccination (Msaouel et al., 2012; Russel et al., 2010). For these reasons, stability studies of MV under production conditions (especially medium, oxygen saturation, ion strength, $\mathrm{pH}$ and temperature) are important to retain the infectivity during upstream and downstream processing. This will be essential for generation of the required doses of infectious virus particles.

Virus inactivation in general was reported to proceed similar to cell dying (Bauer and Henle, 1979; Johnson, 1974) or protein and enzyme inactivation (Weemaes et al., 1997; 1998). All reports about MV stability in general have been published decades ago. Temperature (Black, 1959; Boriskin et al., 1988; Musser et al., 1960; Rapp et al., 1965), pH (Black, 1959; Musser et al., 1960) and salt concentrations (Boriskin et al., 1988; Rapp et al., 1965) were the most important factors analyzed, then. Recently, some work has focused on stability studies for MV vaccines after production and purification (Burger et al., 2008; Ohtake et al., 2010). While these virus particles are stabilized with different agents or are even lyophilized, this stability studies are not representative for measles virus particles under production conditions. The key parameters for MV production for the use in cancer therapy were already discussed in a previous review (Weiss et al., 2012).

The current study aims to target MV stability of MV-batches for high-dose applications such as virotherapy. For process parameters during production and purification the presented data involve determination of temperature inactivation constants, analysis of the impact of $\mathrm{pH}, \mathrm{pO}_{2}$, or certain salts. The determined parameters may serve as a basis for optimizing MV production and purification in future applications such as oncolytic virotherapy requiring comparatively high doses of infectious virus.

\section{MATERIALS AND METHODS}

\subsection{Cells and Virus}

Infectious recombinant $\mathrm{MV}$ particles of the strain $\mathrm{MV}_{\text {vac2 }}$ GFP (P) were rescued and propagated as described previously (Devaux et al., 2007). MV was propagated in Vero cells (\# CCL-81, ATCC) under standard culture conditions. Titers were determined according to (Karber, 1931; Reed and Muench, 1938). Cells were adapted to grow in serum free VPSFM medium (Gibco, Invitrogen) supplemented with $4 \mathrm{mM}$ glutamine (PAA, Germany) over 5 passages and were expanded in $\mathrm{T}$ flasks at $37^{\circ} \mathrm{C}$ and $5 \% \mathrm{CO}_{2}$, without any substituents of animal origin. Infections were performed at a cell density of 50.000 cells $\mathrm{cm}^{-2}$ with an MOI of 0.02 . Measles virus suspensions were collected from the supernatant after centrifugation $(5 \mathrm{~min}, 300 \mathrm{~g}$ (Megafuge 1.0R, Thermo Scientific)).

\subsection{Temperature Stability Studies}

MV suspension were incubated at 4, 22, 32, or $37^{\circ} \mathrm{C}$ in the dark for the indicated time. After exposure at $4^{\circ} \mathrm{C}$, residual virus titers were always determined immediately after sampling. After exposure at $22^{\circ} \mathrm{C}$, $32^{\circ} \mathrm{C}$ or $37^{\circ} \mathrm{C}$ samples were first frozen at $-20^{\circ} \mathrm{C}$ in a radiator block to immediately stop particle decay before titrating residual titers.

\section{3. pH Stability Studies}

MV particle suspensions were supplemented with appropriate volumes of $1 \mathrm{M} \mathrm{NaOH}$ or $1 \mathrm{M} \mathrm{HCl}$ to adjust the $\mathrm{pH}$ to the desired range. The virus solutions at $\mathrm{pH} 5,6$, $7,8,9$ and 10 were titrated according to the $\mathrm{TCID}_{50}$ method immediately after adjustment of $\mathrm{pH}$ and after $3 \mathrm{~h}$ incubation (at $4^{\circ} \mathrm{C}$, in the dark), respectively.

\subsection{Salt Stability Studies}

MV suspensions were incubated with different salt solution at different concentrations. $\mathrm{MgSO}_{4}$ and $\mathrm{NaCl}$ solutions at $1.5 \mathrm{M}, 1 \mathrm{M}, 0.5 \mathrm{M}, 0.25 \mathrm{M}$ and $0.1 \mathrm{M}$ were analyzed. For this purpose, appropriate volumes 
of $3 \mathrm{M}$ stock solution of each salt were given to different aliquots of same virus suspensions to adjust salt concentrations. $\mathrm{TCID}_{50}$ titration of residual infectivity was done immediately after salt supplementation and after $3 \mathrm{~h}$ of incubation. Conductivity measurements of adjusted suspensions were performed using the SevenGoDuoPro device from Mettler Toledo.

\section{5. $\mathrm{pO}_{2}$ Stability Studies}

For the analysis of $\mathrm{pO}_{2}$ stability, MV suspensions were diluted in ice cold phosphate buffer saline at $\mathrm{pH}$ 7.2. Conditions were chosen as currently tested for measles virus production (manuscript in preparation), using impeller stirrer in $1 \mathrm{~L}$ Stirred Tank Reactor (STR).

\section{RESULTS}

\subsection{Measles Virus Thermal Inactivation}

To investigate the $\mathrm{MV}$ inactivation rates at different temperatures, measles virus suspensions were incubated at $37^{\circ} \mathrm{C}, 32^{\circ} \mathrm{C}$ (potential temperatures for production), $22^{\circ} \mathrm{C}$ (room temperature), or $4{ }^{\circ} \mathrm{C}$ (storing temperature) and virus titer were determined after defined time spans.

Figure 1 shows an increase of MV inactivation rates with increasing temperature. At $37^{\circ} \mathrm{C}$ and $32^{\circ} \mathrm{C} \mathrm{MV}$ half-life were one and two hours respectively. When starting with a titer of $6.3 \times 10^{5} \mathrm{TCID}_{50} / \mathrm{mL}$, the MV titer was below the limit of detection $\left(10^{2} \mathrm{TCID}_{50} / \mathrm{mL}\right)$ after an incubation of $23 \mathrm{~h}$ at $37^{\circ} \mathrm{C}$. At $22^{\circ} \mathrm{C}$ and $4{ }^{\circ} \mathrm{C}$, MV was more stable indicated by higher half-life times (18 h and $5 \mathrm{~d}$, respectively).

In Fig. 1 MV inactivation is displayed semilogarithmic. An exponential regression was fitted to the data sets. The exponent of the respective regression lines gives the inactivation rate constant $\mathrm{k}$. According to Arrhenius (Equation 1) the estimated k-values (lnk) against temperature $\left(\mathrm{T}^{-1}\right)$ resulted in a linear correlation (Fig. 2), where the slope represents the term $\mathrm{E}_{\mathrm{A}} \mathrm{R}^{-1}$. Taking Equation 2-4 the thermodynamic parameters enthalpy and entropy can be estimated (Johnson, 1974):

$$
\mathrm{k}=\mathrm{A} \cdot \mathrm{e}^{\frac{\mathrm{E}_{\mathrm{A}}}{\mathrm{R} \cdot \mathrm{T}}}
$$

Where:

$$
\begin{aligned}
& \mathrm{A}=\text { The pre-exponential factor }\left(\mathrm{h}^{-1}\right) \\
& \mathrm{E}_{\mathrm{A}}=\text { The activation energy }\left(\mathrm{kJ} \mathrm{mol}^{-1}\right) \\
& \mathrm{R}=\text { The universal gas constant }\left(\mathrm{kJ} \mathrm{mol}^{-1} \mathrm{~K}^{-1}\right)
\end{aligned}
$$

$\mathrm{T}=$ The temperature $(\mathrm{K})$

$\mathrm{k}=\frac{\mathrm{k}_{\mathrm{B}} \cdot \mathrm{T}}{\mathrm{h}} \cdot \mathrm{e}^{\frac{-\Delta \mathrm{G}}{\mathrm{R} \cdot \mathrm{T}}}$

Eyring Equation, where:

$\mathrm{k}_{\mathrm{B}}=$ The Boltzmann constant $\left(\mathrm{kJ} \mathrm{K}^{-1}\right)$

$\mathrm{h}=$ The Planck's constant (J s)

$\Delta \mathrm{G}=$ Gibbs energy $\left(\mathrm{kJ} \mathrm{mol}^{-1}\right)$

$\Delta \mathrm{H}=\mathrm{E}_{\mathrm{A}}-\mathrm{R} . \mathrm{T}$

$\Delta \mathrm{H}$ is the enthalpy of activation $\left(\mathrm{kJ} \mathrm{mol}^{-1}\right)$ :

$\Delta \mathrm{S}=(\Delta \mathrm{H}-\Delta \mathrm{G}) \cdot \mathrm{T}^{-1}$

$\Delta \mathrm{S}$ is the entropy of activation $\left(\mathrm{kJ} \mathrm{mol}^{-1} \mathrm{~K}^{-1}\right)$.

The estimated thermodynamic parameters for $\mathrm{MV}$ inactivation are presented in Table 1. The enthalpy for measlesvirus inactivation was $104 \mathrm{~kJ} \mathrm{~mol}^{-1}(25 \mathrm{kcal}$ $\left.\mathrm{mol}^{-1}\right)$ and the entropy had a value of $0.08 \mathrm{~kJ} \mathrm{~mol}^{-1}(0.02$ kcal $\mathrm{mol}^{-1}$ ).

\subsection{Measles Virus pH Stability}

To estimate MV stability at various $\mathrm{pH}$ values, MV titers were determined at $\mathrm{pH}$ values between 4 and 11 (Fig. 3).

Directly after $\mathrm{pH}$ adjustment, the $\mathrm{MV}$ titer decreased below the limit of detection at $\mathrm{pH} 4$ and $\mathrm{pH}$ 11. Therefore $\mathrm{MV}$ was referred to be completely inactivatedunder these conditions. In the acid $\mathrm{pH}$ range no infectious MV particles were found $(\mathrm{pH} 5)$ immediately after adjustment or a decrease of approx. 2 orders of magnitude appeared $(\mathrm{pH} 6)$. In the basic $\mathrm{pH}$ range, directly after $\mathrm{pH}$ adjustment to $\mathrm{pH} 8,9$, or 10, MV titers decreased by approx. one order of magnitude ( 1.1 to $1.6 \log _{10}$ units). After $3 \mathrm{~h}$ incubation time at acidic and basic $\mathrm{pH}$ MV titers were close to the detection limit in all approaches.

The highest titer was estimated at $\mathrm{pH} 7$. Interestingly, only small changes in $\mathrm{pH}$ from 7.2 to 7.0 resulted in a titer decrease of one order of magnitude after $3 \mathrm{~h}$ of incubation, highlighting the sensitivity of MV particles against $\mathrm{pH}$ changes.

\subsection{Measles Virus Stability at Different Salt Concentrations}

To estimate whether MV inactivation at various $\mathrm{pH}$ values away from neutral $\mathrm{pH}$ was due to increased salt concentrations, MV infectivity was analyzed at different salt concentrations and conductivities. 
Weiss, K. et al. / American Journal of Biochemistry and Biotechnology 9 (3): 243-254, 2013
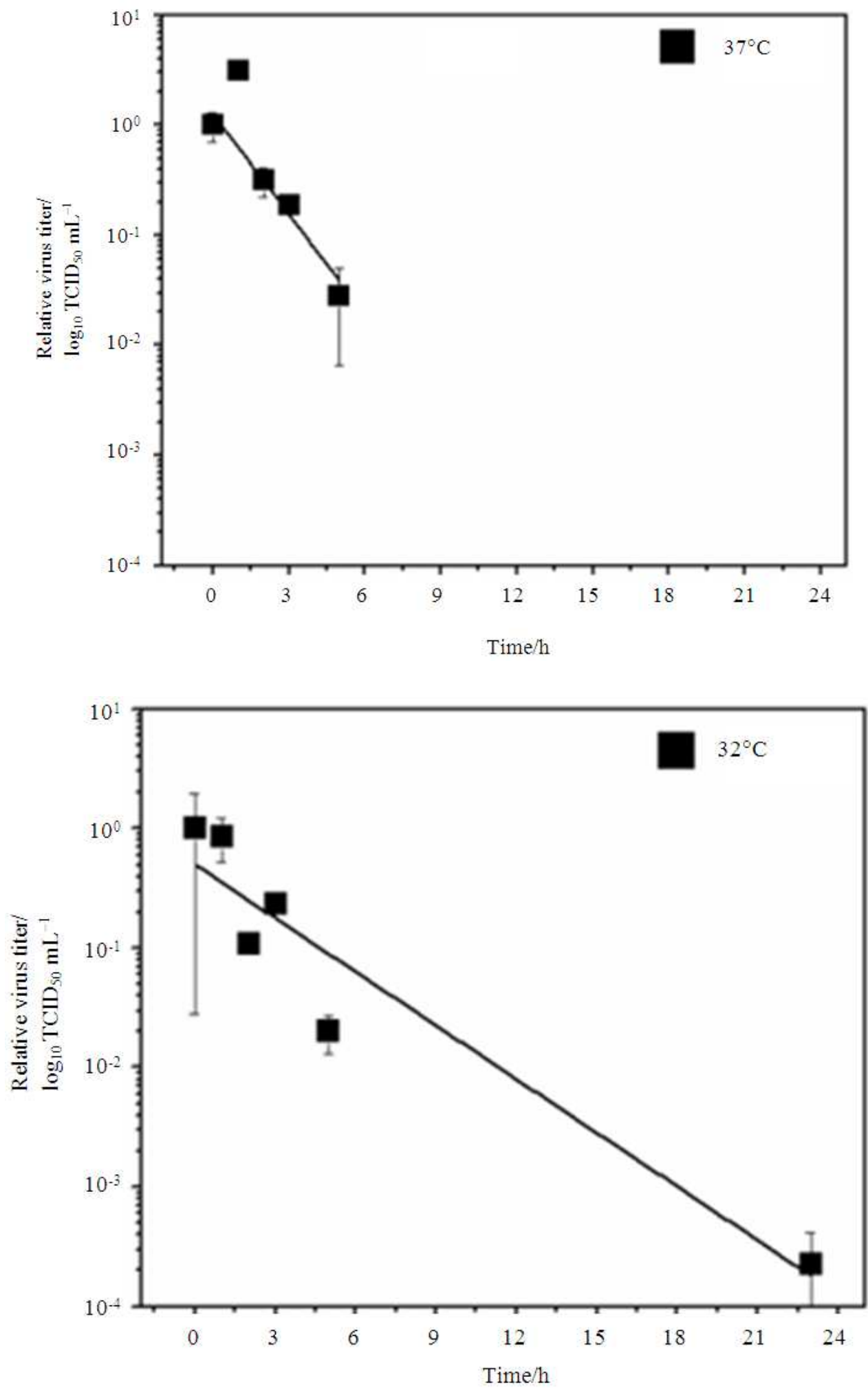
Weiss, K. et al. / American Journal of Biochemistry and Biotechnology 9 (3): 243-254, 2013
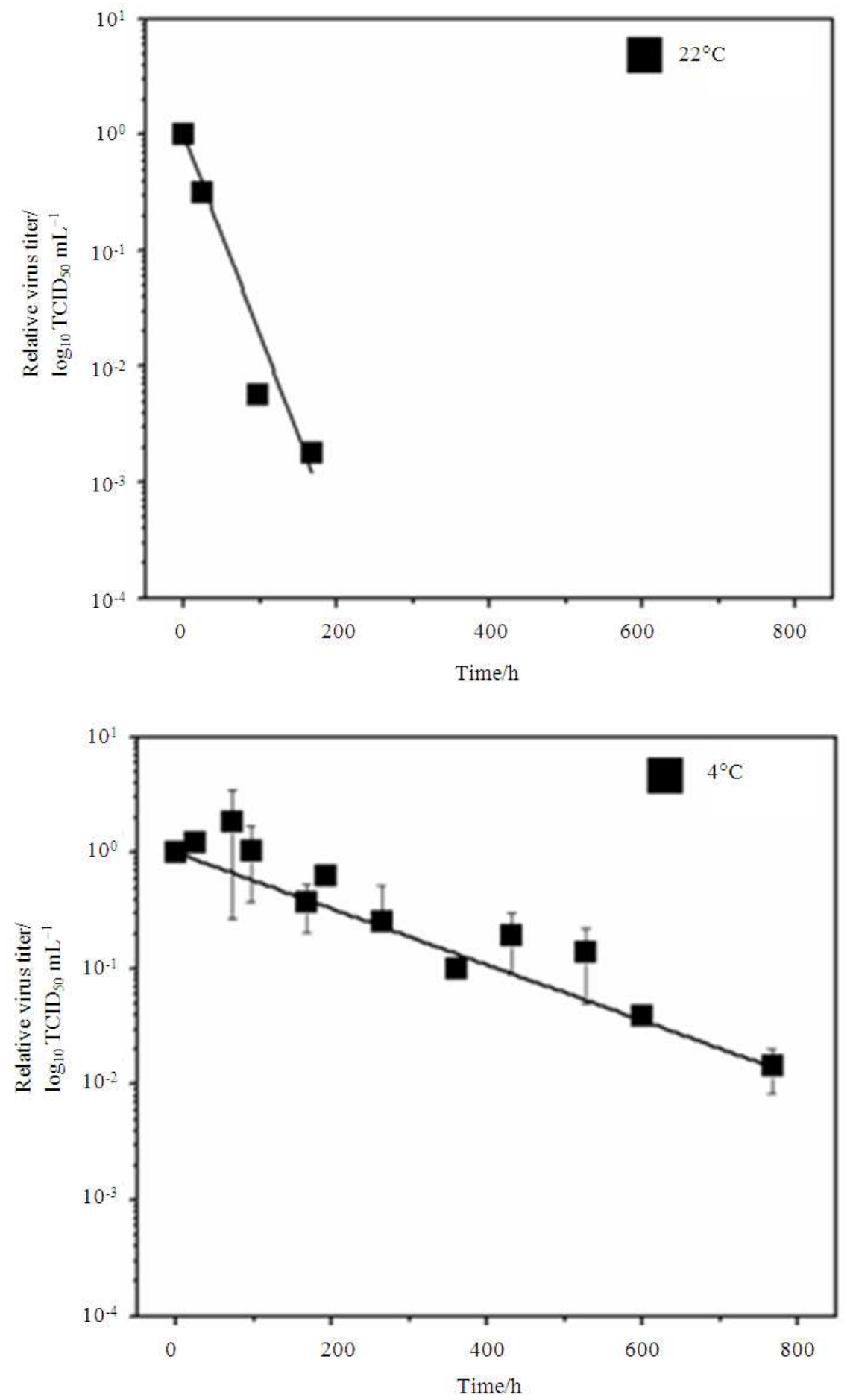

Fig. 1. Thermal inactivation of MV at $37^{\circ} \mathrm{C}, 32^{\circ} \mathrm{C}, 22^{\circ} \mathrm{C}$ and $4{ }^{\circ} \mathrm{C}$. Incubation studies were performed in triplicate, except for the temperature at $22^{\circ} \mathrm{C}$. The virus titers are given as relative values divided by virus titer at time point zero of incubation. Lines represent exponential regression of respective data sets. Error bars indicate standard deviation. 
Weiss, K. et al. / American Journal of Biochemistry and Biotechnology 9 (3): 243-254, 2013

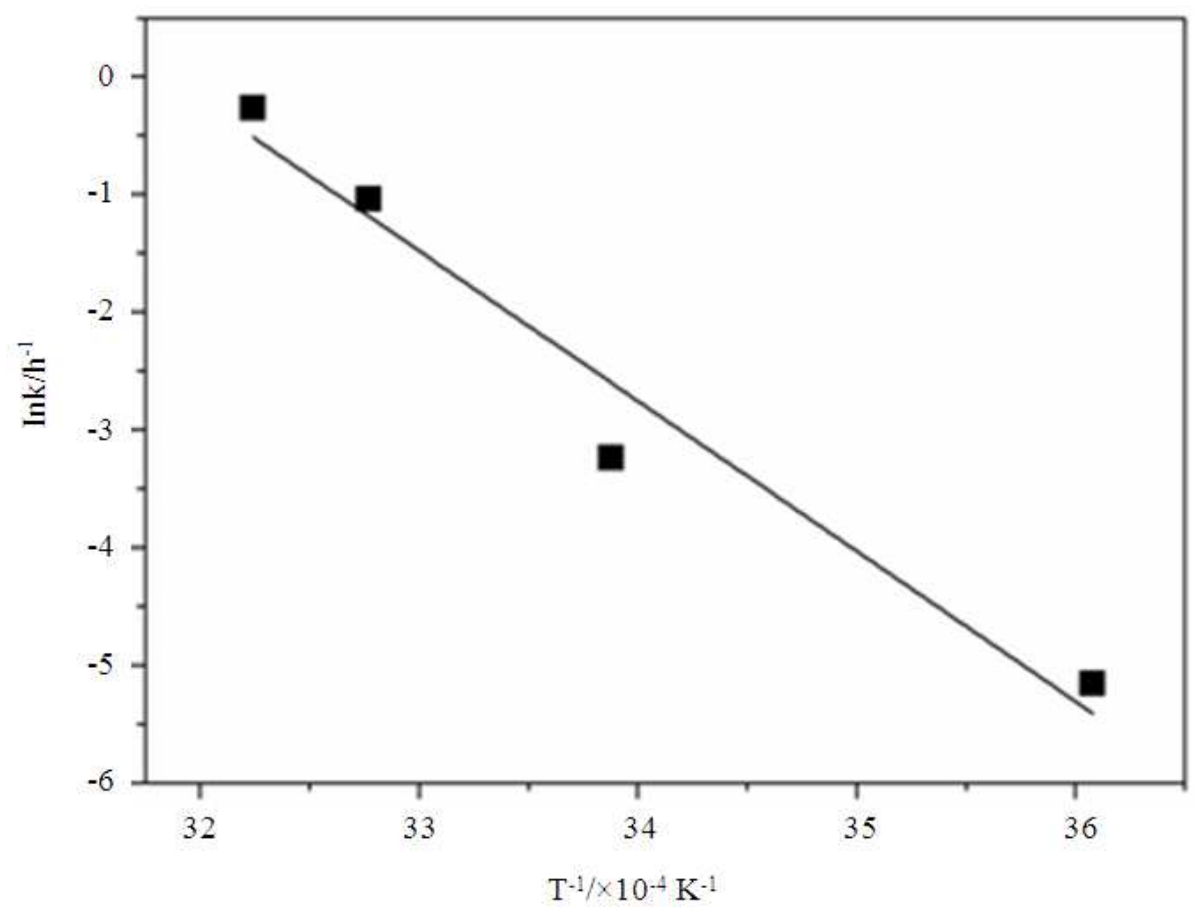

Fig. 2. Arrhenius plot for measles virus thermal inactivation. Values for inactivation constant k were estimated by exponential regression of data sets from Fig. 1.

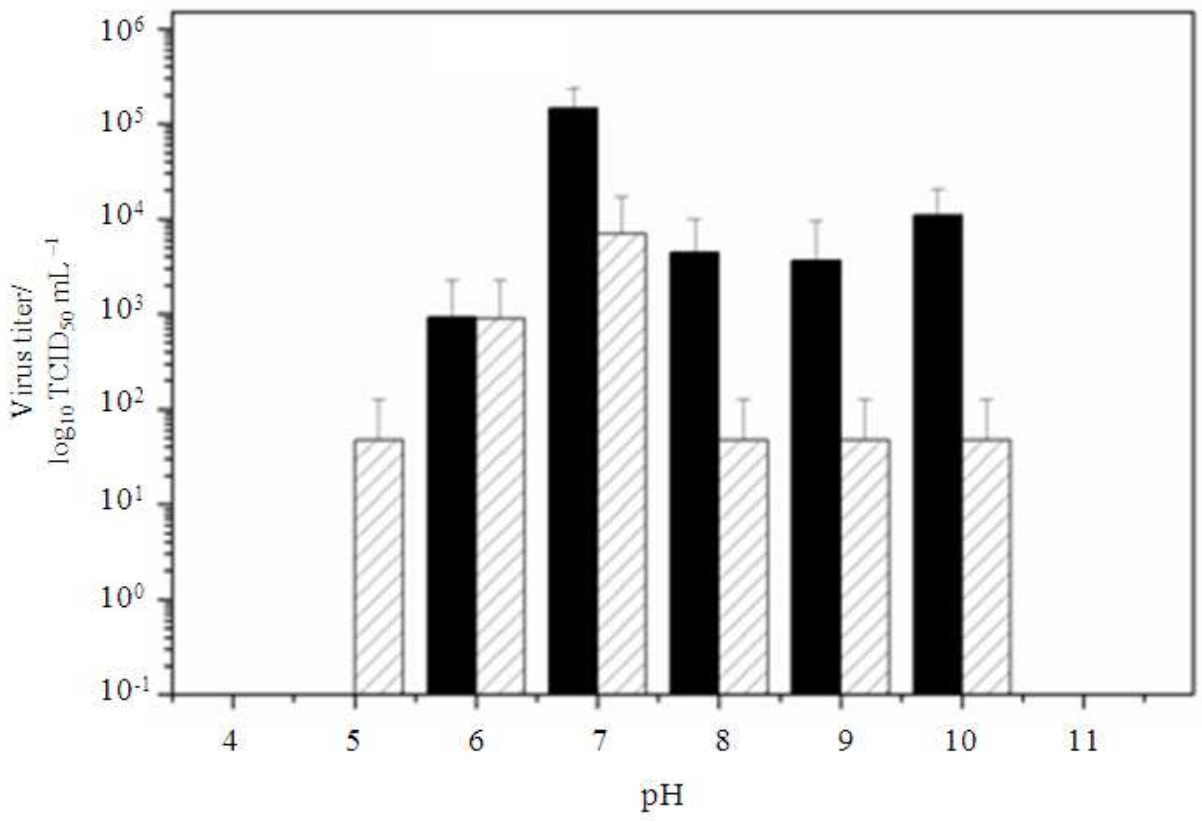

Fig. 3. Inactivation of $\mathrm{MV}$ at different $\mathrm{pH}$. For $\mathrm{pH}$ adjustment of $\mathrm{MV}$ suspensions, respective volumes of $1 \mathrm{M} \mathrm{NaOH}$ and $1 \mathrm{M}$ $\mathrm{HCl}$ were added. Virus titers were determined directly after $\mathrm{pH}$ adjustment (black bars) or after $3 \mathrm{~h}$ incubation in the dark at $4{ }^{\circ} \mathrm{C}$ (hatched bars). 


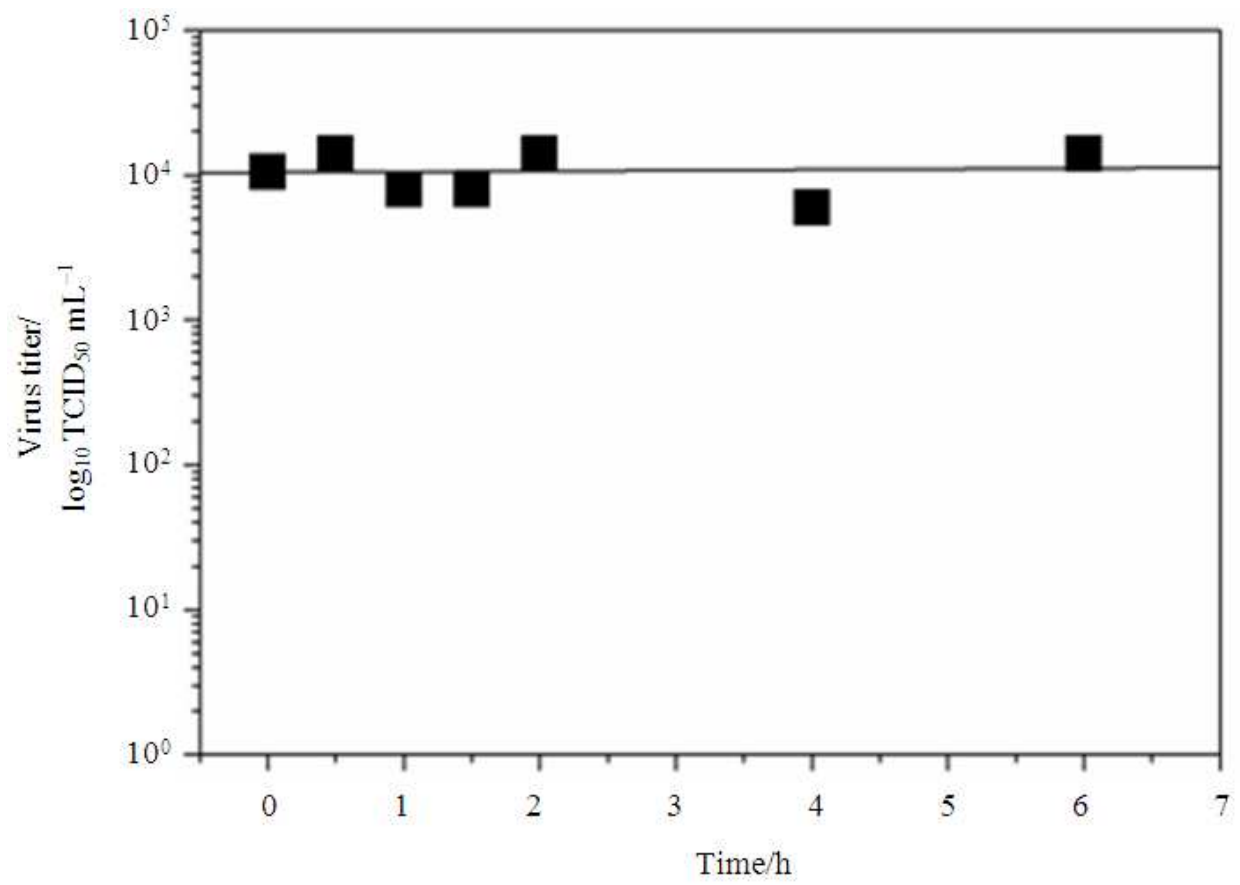

Fig. 4. Oxygen stability of MV particles. Measles virus suspension was stirred in an STR at $70 \mathrm{rpm}, \mathrm{pH} 7.2,0.1 \%$ (w/v) Pluronic F68 and $100 \% \mathrm{pO}_{2}$; samples were taken at the indicated time points and subsequently titrated. The horizontal line at $1 \times 10^{4}$ $\mathrm{TCID}_{50} / \mathrm{mL}$ is displayed for easier comparability of different values.

Table 1. Estimated thermodynamic coefficients for measles virus thermal inactivation

\begin{tabular}{lll}
\hline$\Delta \mathrm{H} / \mathrm{kJ} \mathrm{mol}^{-1}$ & $\Delta \mathrm{S} / \mathrm{kJ} \mathrm{mol}^{-1} \mathrm{~K}^{-1}$ & $\Delta \mathrm{G} / \mathrm{kJ} \mathrm{mol}^{-1}$ \\
\hline 104 & 0.08 & 78 \\
$\Delta \mathrm{H} / \mathrm{kcal} \mathrm{mol}^{-1}$ & $\Delta \mathrm{S} / \mathrm{kcal} \mathrm{mol}^{-1} \mathrm{~K}^{-1}$ & $\Delta \mathrm{G} / \mathrm{kcal} \mathrm{mol}^{-1}$ \\
25 & 0.02 & 19 \\
\hline
\end{tabular}

Table 2. Measles virus stability at different conductivities in diluted water and in $\mathrm{NaCl}$ and $\mathrm{MgSO}_{4}$ salt solutions

$$
\log _{10} \mathrm{TCID}_{50} \mathrm{~mL}^{-1}
$$

\begin{tabular}{llll} 
Sample name & Conductivity $/ \mathrm{mS} \mathrm{cm}^{-1}$ & Directly & After 3 h incubation \\
\hline Reference & 013.28 & $6.10 \pm 0.17$ & $6.47 \pm 0.23$ \\
$1.5 \mathrm{M} \mathrm{NaCl}$ & 137.50 & $6.19 \pm 0.42$ & $6.60 \pm 0.44$ \\
$1 \mathrm{M} \mathrm{NaCl}$ & 094.30 & $6.21 \pm 0.15$ & $6.31 \pm 0.55$ \\
$0.5 \mathrm{M} \mathrm{NaCl}$ & 054.70 & $6.07 \pm 0.06$ & $6.46 \pm 0.53$ \\
$0.25 \mathrm{M} \mathrm{NaCl}$ & 037.80 & $5.92 \pm 0.30$ & $6.39 \pm 0.69$ \\
$0.1 \mathrm{M} \mathrm{NaCl}$ & 023.99 & $5.83 \pm 0.11$ & $6.66 \pm 0.43$ \\
$1.5 \mathrm{M} \mathrm{MgSO}_{4}$ & 059.80 & $5.96 \pm 0.47$ & $6.05 \pm 0.27$ \\
$1 \mathrm{M} \mathrm{MSO}_{4}$ & 052.90 & $6.13 \pm 0.43$ & $6.62 \pm 0.35$ \\
$0.5 \mathrm{M} \mathrm{MgSO}_{4}$ & 040.10 & $6.18 \pm 0.35$ & $6.26 \pm 0.28$ \\
$0.25 \mathrm{M} \mathrm{MgSO}_{4}$ & 032.10 & $6.57 \pm 0.23$ & $6.18 \pm 0.54$ \\
$0.1 \mathrm{M} \mathrm{MgSO}_{4}$ & 030.42 & $6.98 \pm 0.43$ & $6.06 \pm 0.11$ \\
Dilution factor (aquadest): & & & $6.12 \pm 0.51$ \\
2 & 006.71 & $6.37 \pm 0.26$ & $6.01 \pm 0.19$ \\
5 & 002.78 & $6.39 \pm 0.19$ & $5.77 \pm .0 .25$ \\
10 & 001.49 & $6.15 \pm 0.13$ & \\
\hline
\end{tabular}


In Table 2, virus titers determined at different conductivities and salt concentrations are displayed. Neither measles virus suspensions with $\mathrm{NaCl}$, or $\mathrm{MgSO}_{4}$ at 0.1 to $1.5 \mathrm{M}$, respectively, nor up to 10 -fold dilutions with distilled water resulted in significant virus titer decrease. Therefore, measles virus was observed to be very stable at conductivities between 1.5 to $137.5 \mathrm{mS}$ $\mathrm{cm}^{-1}$. Thus, a decrease of virus titer under different $\mathrm{pH}$ conditions can be addressed to different proton concentrations, not salt ions or conductivities.

\subsection{Measles Virus Oxygen Stability}

As MV is produced by an aerobically host cell, oxygen supply and sensitivity might play an important role for MV production. For this reason an exemplary analysis was done to estimate MV stability under production conditions. Measles virus suspension was stirred in STR at pH 7.2, $70 \mathrm{rpm}, 8^{\circ} \mathrm{C}$ and $100 \% \mathrm{pO}_{2}$ Fig. 4.

Within $6 \mathrm{~h}$, the virus titer did not vary to a significant level, so no inactivation has been observed due to high oxygen partial pressure. Under the above described conditions, oxygen concentration according to MV particles inactivation is not a critical factor for MV production.

\section{DISCUSSION}

For the application of measles virus in cancer therapy up to $1,000,000$ more infectious virus particles are needed compared to vaccination (Russel et al., 2010). For this reason, first, an effective oncolytic measles virus production process should be established or the measles virus has to be highly concentrated with preserved infectivity to get these high titers. Second, since a successful therapy will be dependent on the infectivity of the virus particles, measles virus stability is an important issue and has to be integrated into MV production considerations. In this study stability studies of infectious MV suspensions in serum free medium are presented aiming to analyze the impact of conditions like $\mathrm{pH}$ or temperature that play an important role during production of MV in upstream and downstream processing. Finally, critical parameters were identified to further raise MV yields for the relative high amount needed e.g., for cancer therapy approaches (Russel et al., 2010).

The parameter temperature is a very important factor, as temperatures around $30^{\circ} \mathrm{C}$ are minimally required for the host cell maintenance metabolism and even for virus production. Contrary MV (Edmonston strain) has been reported to be very sensitive towards temperatures above $30^{\circ} \mathrm{C}$, (Black, 1959; Kohn and
Yassky, 1962; Musser et al., 1960; Rapp et al., 1965). A half-life of two hours was determined at $37^{\circ} \mathrm{C}$ for the Edmonston strain, according to about $100 \%$ loss within $4 \mathrm{~h}$ (Black, 1959), while a decrease in virus titer of $90 \%$ within $16 \mathrm{~h}$ was reported by (Kohn and Yassky, 1962) and within $13 \mathrm{~h}$ by (Musser et al., 1960). The AIK-C MV strain at $28^{\circ} \mathrm{C}$ incubation was completely inactivated within 3 days (a loss of over 7 orders of magnitudes) and at $4{ }^{\circ} \mathrm{C}$ the virus titer decreased about $2 \log _{10}$ units within 10 days and remained after that stable for another 2 days (Trabelsi et al., 2012). The Edmonston strain lost its infectivity at $23^{\circ} \mathrm{C}$ with a rate of approx. one order of magnitudes in $24 \mathrm{~h}$ (Black, 1959). In accordance with the data presented here, inactivation at $37^{\circ} \mathrm{C}$ or $32^{\circ} \mathrm{C}$ occurs with a half-life of just 1 or $2 \mathrm{~h}$, respectively, where an inactivation at room temperature or at $4^{\circ} \mathrm{C}$ was significantly slower (Fig. 1).

The medium of the MV suspension seems to be an important factor for MV stability at different temperatures. The present studies were done in serum free VPSFM, as this medium is suitable for MV production under serum free conditions (own unpublished data). As already mentioned above, the halflife determined in the current set-up were quite comparable to those reported in Eagle's medium supplemented with $10 \%$ calf serum (Black, 1959), where a half-life of two hours was determined at $37^{\circ} \mathrm{C}$. In medium 199 without serum, a drop of infectivity of 2.4 $\log _{10}$ units has been demonstrated after $7 \mathrm{~h}$ incubation at $25^{\circ} \mathrm{C}$. At $37^{\circ} \mathrm{C}$ no virus inactivation could be observed $\left(3.2+/-0.2 \log _{10} \mathrm{TCID}_{50} \mathrm{~mL}^{-1}\right)$ but after $24 \mathrm{~h}$ a drop of two $\log _{10}$ units appeared (Musser et al., 1960). Nevertheless, this is the only report about a higher stability at a higher temperature for measles virus. This is in contrast to the data presented in this study.

Interestingly, a higher inactivation rate was reported at $6^{\circ} \mathrm{C}$, when $\mathrm{MV}$ particles were prepared in serum free medium. At this temperature, MV titers decreased to $10 \%$ of original titers in serum free preparations within 4 weeks, while in serum containing medium the virus titer was more or less stable $\left(5+/-0.3 \log _{10} \mathrm{TCID}_{50} \mathrm{~mL}^{-1}\right)$ (Musser et al., 1960). In water-suspensions, MV preparations lost $90 \%$ of infectivity within $24 \mathrm{~h}$ at $4^{\circ} \mathrm{C}$ and $50 \%$ within $1 \mathrm{~h}$ at $25^{\circ} \mathrm{C}$ (Rapp et al., 1965). This shows that measles virus particles in suspension need certain supplements to retain their infectivity. While serum was reported to be very effective, other supplements like sugar, amino acids and divalent ions were already reported to preserve measles virus infectivity (Trabelsi et al., 2012). 
The thermal inactivation reactions follow first order kinetics for all analyzed temperatures (Fig. 1), which is also reported for tobacco mosaic virus (Ginoza, 1958), Sindbis virus (Barnes et al., 1969) and baculovirus (Gotoh et al., 2008). The corresponding Arrhenius plot (Fig. 2) indicates only one process parameter that contributes to $\mathrm{MV}$ inactivation due to temperature sensitivity in our experimental setting. A two component mode mechanism of inactivation in which inactivation proceeds in the first place in a faster manner and then a slower degradation is observed that follows first order kinetics had been reported for lyophilized measles vaccine (Allison et al., 1981; Colinet et al., 1982). For unprocessed $\mathrm{MV}$ at $45^{\circ} \mathrm{C}$ and $50^{\circ} \mathrm{C}$ this so called two component mode has also been shown for the Schwarz and Mantooth strain (Albrecht and Schumacher, 1972) and at $4^{\circ} \mathrm{C}$ for the AIK-C strain (Trabelsi et al., 2012). For the Edmonston MV strain a two component inactivation was suggested only by the data $a 5^{\circ} \mathrm{C}$ or $50^{\circ} \mathrm{C}$ (Rapp et al., 1965).

In a previous study (Woese, 1960), an enthalpy of 20 $\mathrm{kcal} \mathrm{mol}^{-1}$ and an entropy of $-19 \mathrm{cal} \mathrm{mol}^{-1}{ }^{\circ} \mathrm{C}^{-1}$ had been determined for Tobacco Mosaic Virus (TMV) RNA which was designated to be associated with RNA inactivation. In general RNA inactivation was accompanied by a small value for enthalpy and a negative value for entropy. In the same study, positive entropy values between 3 to $950 \mathrm{cal} \mathrm{mol}^{-1}{ }^{\circ} \mathrm{C}^{-1}$ of thermal inactivation were reported for proteins, bacterial and plant viruses and other animal viruses (Woese, 1960). The thermodynamic parameters for MV inactivation as determined in this study are summarized in Table 1. The enthalpy and entropy for thermal inactivation of $\mathrm{MV}$ were $25 \mathrm{kcal} \mathrm{mol}^{-1}$ and $20 \mathrm{cal}$ $\mathrm{mol}^{-1} \mathrm{~K}^{-1}$, respectively. According to Woese (1960), the values in this study could suggest that measles virus inactivation is accompanied by both RNA and protein inactivation. For the enthalpy of measles virus heat inactivation values of 18 to $70 \mathrm{kcal} \mathrm{mol}^{-1}\left(23^{\circ} \mathrm{C}\right.$ to $\left.56^{\circ} \mathrm{C}\right)$ were reported in the literature (Woese, 1960). As the enthalpy is greater than zero the reaction is so called endothermic, which means that for measles virus inactivation energy must be absorbed into the system. According to the second law of thermodynamic, an entropy larger than zero indicates an irreversible reaction, meaning that in this study MV thermal inactivation is estimated to be a non-reversible process. Measles virus thermal inactivation as a reversible process, according to entropy of zero, has never been reported and such back formation without any permanent alteration of the system or its surrounding is not expected for a biological system.

Similar to Murine Leukemia Virus (MLV) production, the high degradation rate at $37^{\circ} \mathrm{C}$ (Nehring et al., 2006) presents a new challenge for the production process. To achieve the high amounts of infectious virus particels virus filtration for concentration is a possible solution, like it has been reported for MLV, (Nehring et al., 2004; 2009), densonucleosis virus (Czermak et al., 2008; Grzenia et al., 2006; Specht et al., 2004), recombinant baculovirus (Grein et al., 2012; Michalsky et al., 2009; 2010) and minute virus (Hensgen et al., 2010). MV purification in a scale of up to $60 \mathrm{~L}$ is already reported by Langfield et al. (2011), but especially the half-life of 2 and $1 \mathrm{~h}$ of $\mathrm{MV}$ particles at 32 and $37^{\circ} \mathrm{C}$, respectively, suggests inline filtration with continues harvest and immediate cooling like it has already been reported for MLV particles (Nehring et al., 2009).

Referring to $\mathrm{pH}$ stability, the data in this report (Fig. 3) reveal that MV is very sensitive towards changes away from neutral ( $\mathrm{pH}$ 7.2). This shows that process conditions have to be adjusted during upstream and downstream processing. Inactivation of $\mathrm{MV}$ due to $\mathrm{pH}$ sensitivity has already been presented, before. Similar to the results presented here, a total virus inactivation at $\mathrm{pH}$ $>10$ or $<5$ has been reported (Musser et al., 1960). Stable virus titers were identified between $\mathrm{pH} 7$ and 8 , whereas between $\mathrm{pH} 5$ and 7 or 8 and 9 inactivation was between one to two $\log _{10}$ units (Musser et al., 1960). Black reported a maximum virus titer of $7.9 \times 10^{3} \mathrm{pfu}$ at $\mathrm{pH} 7.6$, a stable titer from $\mathrm{pH} 6$ to 10.5 (maximum decrease of $0.6 \log _{10}$ units), but a comparably high inactivation at $\mathrm{pH} 4.4,3.8$ and 2.4 of $2.8 \log _{10}$ units, representing a loss of $80 \%$ (Black, 1959). Such sensitivity towards $\mathrm{pH}$ changes was also reported for recombinant baculovirus. In this case particles aggregation due to $\mathrm{pH}$ changes has been suggested to be responsible for the observed virus inactivation (Grein et al., 2012). The data show that for an optimized production process $\mathrm{pH}$ regulation in narrow limits during upstream and downstream processing is essential to preserve measles virus infectivity.

As depicted in Table 2, MV titers did not significantly decrease with either a rising or falling conductivity. This stability of MV under different salt concentrations indicates that the sensitivity of $\mathrm{MV}$ to $\mathrm{pH}$ differing from neutral was not due to enhanced ion concentrations, but linked to proton concentration. The ions $\mathrm{Ca}^{2+}, \mathrm{Zn}^{2+}$ and $\mathrm{Mg}^{2+}$ can be associated to different proteins and especially $\mathrm{MgSO}_{4}$ was reported to improve MV stability or even production yield (Boriskin et al., 
1988; Rapp et al., 1965; Trabelsi et al., 2012). While a negative impact of $\mathrm{MgSO}_{4}$ on measles virus could not be observed in the present study, it possibly improves the virus yield during production.

To date, no analysis concerning the sensitivity of MV towards oxygen has been published. However, this parameter is essential in bioprocess evaluation and scale up investigations as it is necessary for the growth of the mammalian host cells. Especially in scale up investigations dealing with high cell concentrations aeration and the oxygen partial pressure is an important factor. The negative effect of oxygen is given by the formation of oxygen radicals in redox reactions by several enzymes. Oxygen radicals are highly reactive and contingently destructive to biomolecules or its functional groups. Therefore, high oxygen concentrations potentially resulting in generation of larger amounts of oxygen radicals may be counterproductive for virus stability due to biochemical redox reactions e.g., with subsequent inactivation of viral surface proteins critical for infectivity (Lim et al., 1999). For these reasons it was analyzed, whether oxygen is a critical parameter for MV stability. For an exemplary test, small scale laboratory conditions were chosen, where measles virus production is currently evaluated (manuscript in preparation). Under these conditions MV titers were stable at an oxygen partial pressure of $100 \%$, indicating resistance of $\mathrm{MV}$ particles against inactivation under high oxygen concentrations. The result presented shows that in scale up investigations a high oxygen demand of Vero cell cultures after infection is no critical factor after infection, whereby this enables working at high cell concentrations.

In summary, this study shows which parameters should be considered for further production evaluation. Identified critical parameters could be controlled strongly in the production process to further raise measles virus yields for the high amount needed in cancer therapy approaches. High thermal inactivation should be considered when thinking about time of harvest or continuous cooling during downstream processing. A half-life of 1 and $2 \mathrm{~h}$ at 37 and $32^{\circ} \mathrm{C}$, respectively, shows that harvest of measles virus particles should be performed several fold or even continuously. After that immediate cooling of the virus suspension is essential to retain the infectivity. $\mathrm{pH}$ sensitivity is also an important factor when thinking about automatic $\mathrm{pH}$ regulation during measles virus production. Interestingly, measles virus showed no sensitivity towards an oxygen partial pressure of $100 \%$ or varying conductivities between 1.4 and $138 \mathrm{mS} \mathrm{cm}^{-1}$. Measles virus stability towards different salt concentrations could be an advantage in purification approaches using ion exchange membrane chromatography. This purification has already been reported for recombinant baculovirus (Grein et al., 2012) and densonucleosis virus (Specht et al., 2004).

\section{CONCLUSION}

The results presented show how process parameters could affect final infectious MV yields at production and purification.

Aiming for high amounts of infectious MV particles for the applications in cancer therapy, future studies should go in more detailed investigations for $\mathrm{MV}$ stability and should also integrate them into the evaluation of MV production.

\section{ACKNOWLEDGEMENT}

The authors are indepted to Roberto Cattaneo for providing $\mathrm{MV}_{\text {vac2 }}$-GFP (P). M.D.M. was supported by the Deutsche Krebshilfe (109614) and the Federal Ministry for Education and Research of Germany (BMBF) grants of the German Center for Infection Research.

The researchers would like to thank the Hessen State Ministry of Higher Education, Research and the Arts for the financial support within the Hessen initiative for scientific and economic excellence (LOEWE-program).

\section{REFERENCES}

Albrecht, P. and H.P. Schumacher, 1972. Markers for measles virus. I. Physical properties. Arch. Gesamte Virusforsch, 36: 23-35. PMID: 4622263

Allison, L.M.C., G.F. Mann, F.T. Perkins and A.J. Zuckerman, 1981. An accelerated stability test procedure for lyophilized measles vaccines. J. Biol. Stand., 9: 185-194. DOI: 10.1016/S00921157(81)80022-4

Anderson, B.D., T. Nakamura, S.J. Russell and K.W. Peng, 2004. High CD46 receptor density determines preferential killing of tumor cells by oncolytic measles virus. Cancer Res., 64: 4919-4926. PMID: 15256464

Barnes, R., H. Vogel and I. Gordon, 1969. Temperature of compensation: Significance for virus inactivation. Proc. Nat. Acad. Sci. USA., 62: 263-270. PMCID: PMC285982 
Bauer, K.D. and K.J. Henle, 1979. Arrhenius analysis of heat survival curves from normal and thermotolerant CHO cells. Radiat. Res., 78: 251-263. PMID: 451155

Black, F.L., 1959. Growth and stability of measles virus. Virology, 7: 184-192. DOI: 10.1016/00426822(59)90186-2

Boriskin, Y.S., L.L. Steinberg, L.V. Dorofeeva, I.N. Zasorina and E.P. Barkova, 1988. Salt-induced enhancement of measles virus yields in cultured cells. Arch. Virol., 101: 131-136. DOI: 10.1007/BF01314658

Burger, J.L., S.P. Cape, C.S. Braun, D.H. McAdams and J.A. Best, 2008. Stabilizing formulations for inhalable powders of live-attenuated measles virus vaccine. J. Aerosol. Med. Pulm. Drug. Deliv., 21: 25-34. DOI: $10.1089 /$ jamp.2007.0658

Colinet, G., J. Rossignol and J. Peetermans, 1982. A study of the stability of a bivalent measles-mumps vaccine. J. Biol. Stand., 10: 341-346. DOI: 10.1016/S0092-1157(82)80011-5

Czermak, P., D.L. Grzenia, A. Wolf, J.O. Carlson and R. Specht, 2008. Purification of the densonucleosis virus by tangential flow ultrafiltration and by ion exchange membranes. Desalination, 224: 23-27. DOI: 10.1016/j.desal.2007.04.074

Devaux, P., V. Messling, W. Songsungthong, C. Springfeld and R. Cattaneo, 2007. Tyrosine 110 in the measles virus phosphoprotein is required to block STAT1 phosphorylation. Virology, 360: 7283. DOI: 10.1016/j.virol.2006.09.049

Ginoza, W., 1958. Kinetics of heat inactivation of ribonucleic acid of tobacco mosaic virus. Nature, 181: 958-961. DOI: 10.1038/181958a0

Gotoh, T., N. Ando and K. Kikuchi, 2008. Analysis of inactivation of AcMNPV under various conditions by the ELVA method. Biosci. Biotechnol. Biochem.,72: 1973-1976. PMID: 18603767

Grein, T.A., R. Michalsky, V. Lopez and M. Czermak, 2012. Purification of a recombinant baculovirus of Autographa californica $\mathrm{M}$ nucleopolyhedrovirus by ion exchange membrane chromatography. J. Virol. Methods, 183: 117-124. DOI: 10.1016/j.jviromet.2012.03.031

Grote, D., S.J. Russell, T.I. Cornu, R. Cattaneo and R. Vile, 2001. Live attenuated measles virus induces regression of human lymphoma xenografts in immunodeficient mice. Blood, 97: 3746-3754. DOI: 10.1182/blood.V97.12.3746
Grzenia, D.L., J.O. Carlson, P. Czermak, B. Han and R.K. Specht, 2006. Purification of densonucleosis virus by tangential flow ultrafiltration. Biotech. Prog., 22: 1346-1353. PMID: 17022673

Hensgen, M.I., P. Czermak, J.O. Carlson and S.R. Wickramasinghe, 2010. Purification of minute virus of Mice using high performance tangential flow filtration. Desalination, 250: 1121-1124. DOI: 10.1016/j.desal.2009.09.122

Johnson, H.A., 1974. On the thermodynamics of cell injury. Some insights into the molecular mechanisms. Am. J. Pathol., 75: 13-25. PMID: 4207703

Karber, G., 1931. Beitrag zur kollektiven behandlung pharmakologischer reihenversuche. Arch. Exp. Path. Pharmak, 162: 480-483. DOI: 10.1007/BF01863914

Kohn, A. and D. Yassky, 1962. Growth of measles virus in $\mathrm{KB}$ cells. Virology, 17: 157-163. DOI: 10.1016/0042-6822(62)90092-2

Langfield, K.K., H.J. Walker, L.C. Gregory and M.J. Federspiel, 2011. Manufacture of measles viruses. Methods Mol. Biol., 737: 345-366. DOI: 10.1007/978-1-61779-095-9_14

Lim, H.S., K.H. Chang and J.H. Kim, 1999. Effect of oxygen partial pressure on production of animal virus (VSV). Cytotechnology, 31: 265-270. DOI: 10.1023/A:1008060502532

Michalsky, R., A.L. Passarelli, P.H. Pfromm and P. Czermak, 2009. Purification of the baculovirus Autographa californica M nucleopolyhedrovirus by tangential flow ultrafiltration. Desalination, 245: 694-700. DOI: 10.1016/j.desal.2009.02.039

Michalsky, R., A.L. Passarelli, P.H. Pfromm and P. Czermak, 2010. Concentration of the baculovirus Autographa californica M nucleopolyhedrovirus (AcMNPV) by ultrafiltration. Desalination, 250: 1125-1127. DOI: 10.1016/j.desal.2009.09.123

Msaouel, P., I.D. Iankov, A. Dispenzieri, A. and E. Galanis, 2012. Attenuated oncolytic measles virus strains as cancer therapeutics. Curr Pharm Biotechnol., 17: 1732-1741. PMID: 21740361

Msaouel, P., I.D. Iankov, C. Allen, J.C. Morrisand and V.V. Messling et al., 2009. Engineered measles virus as a novel oncolytic therapy against prostate cancer. Prostate, 69: 82-91. DOI: 10.1002/pros. 20857

Musser, S.J., G.E. Underwood, S.D. Weed and J.L. Ossewaarde, 1960. Studies on measles virus II. Physical properties and inactivation studies of measles virus. J. Immunol., 85: 292-297. 
Navaratnarajah, C.K., V.H. Leonard and R. Cattaneo, 2009. Measles virus glycoprotein complex assembly, receptor attachment and cell entry. Curr. Top. Microbiol. Immunol., 329: 59-76. PMID: 19198562

Nehring, D., R. Portner, M. Schweizer, K. Cichutek and P. Czermak, 2009. Integrated inline filtration: A method to produce highly concentrated retroviral vector titer supernatant. Desalination, 246: 241-247. DOI: 10.1016/j.desal.2009.02.027

Nehring, D., P. Czermak, J. Vorlop and H. Lübben, 2004. Experimental study of a ceramic microsparging aeration system in a pilot-scale animal cell culture. Biotechnol. Prog., 20: 17101717. PMID: 15575703

Nehring, D., R. Gonzalez, R. Portner and P. Czermak, 2006. Experimental and modelling study of different process modes for retroviral production in a fixed bed reactor. J. Biotechnol., 122: 239-253. DOI: 10.1016/j.jbiotec.2005.09.014

Ohtake, S., R.A. Martin, L. Yee, D. Chen and D.D. Kristensen, 2010. Heat-stable measles vaccine produced by spray drying. Vaccine, 28: 1275-1284. DOI: $10.1016 /$ j.vaccine.2009.11.024

Peng, K.W., C.J. TenEyck, E. Galanis, K.R. Kalli and L.C. Hartmann, 2002. Intraperitoneal therapy of ovarian cancer using an engineered measles virus. Cancer Res., 62: 4656-4662. PMID: 12183422

Rapp, F., J.S. Butel and C. Wallis, 1965. Protection of measles virus by sulfate ions against thermal inactivation. J. Bacteriol., 90: 132-135.

Reed, L.J. and H. Muench,1938. A simple method of estimating fifty per cent endpoints. Am. J. Hygiene, 27: 493-497.
Russel, S.J., A.K. Fielding, K.W. Peng and D. Grote, 2010. Method for limiting the growth of cancer cells using an attenuated measles virus. Grant.

Sabella, C., 2010. Measles: Not just a childhood rash. Cleve Clin. J. Med., 77: 207-213. DOI: 10.3949/ccjm.77a.09123

Specht, R., B. Han, S.R. Wickramasinghe, J.O. Carlson and P. Czermak, 2004. Densonucleosis virus purification by ion exchange membranes. Biotechnol. Bioeng., 88: 465-473. PMID: 15384051

Trabelsi, K., S. Majoul, S. Rourou and H. Kallel, 2012. Development of a measles vaccine production process in MRC-5 cells grown on cytodex 1 microcarriers and in a stirred bioreactor. Applied Microbiol. Biotechnol., 93: 1031-1040. DOI: 10.1007/s00253-011-3574-y

Weemaes, C.A., C. De, S.V. Ludikhuyze, L.R. Van and I. Broeck, 1997. Influence of $\mathrm{pH}$ benzoic acid EDTA and glutathione on the pressure and/or temperature inactivation kinetics of mushroom polyphenoloxidase. Biotechnol. Prog., 13: 25-32. PMID: 9041708

Weemaes, C.A., L.R. Ludikhuyze, D. Van, I. Broeck and M.E. Hendrickx, 1998. Kinetics of combined pressure-temperature inactivation of avocado polyphenoloxidase. Biotechnol. Bioeng., 60: 292300. PMID: 10099431

Weiss, K., D. Salzig, M.D. Mühlebach, K. Cichutek and R. Pörtner, 2012. Key parameters of measles virus production for oncolytic virotherapy. Am. J. Biochem. Biotechnol., 8: 81-98. DOI: 10.3844/ajbbsp.2012.81.98

Woese, C., 1960. Thermal inactivation of animal viruses. Ann. New York Acad. Sci., 83: 741-751. DOI: 10.1111/j.1749-6632.1960.tb40943.x 